정두이 · 송정아

경북대학교 섬유패션디자인학부

\title{
A Study on the Combinative Patterns of Lapel and Collar in Tailored Jackets with Different Break Line
}

\author{
Doo-Yi Jung and Jung-A Song ${ }^{\dagger}$ \\ School of Textile Engineering \& Fashion Design, Kyungpook National University; Sangju, Korea
}

\begin{abstract}
This study looks into the changes in collar patterns in tailored jackets with different numbers of buttons. The study discusses the pattern design method of tailored colors in 4 different styles, such as the effect of the number of buttons of tailored jackets on collar width and length, lapel width and length, and angle of lapel and overall balance in design. Through the first dress experiment, patterns were adjusted and corrected. The second dress experiment was conducted with the modified experimental clothes. The results of comparison and analysis are as follows. The 1 button tailored jacket was most preferred for its beautiful expression and overall balance of upper color and lapel when its lapel width was $7.5 \mathrm{~cm}$. The second most preferred one was the 2 button tailored jacket with lapel width of $8 \mathrm{~cm}$, and the 3 button jacket showed relatively good balance when its lapel width was $7.5 \mathrm{~cm}$. The 4 button tailored jacket showed a bad balance in collar and button. Also, its overall silhouette was disappointing and thus was less preferred than others. For smaller number of buttons, the angle of lapel's break line increased, thus displaying a more refined and slim silhouette. On the other hand, the angle of lapel's break line decreased for greater number of buttons, thus displaying a dull and fat image. As a result, the jacket with many buttons was less preferred.
\end{abstract}

Key words: tailored jacket (테일러드 재킷), angle of lapel (라펠의 각도), break line(꺾임선), the effect of the number of Button(여밈 단추수의 영향)

\section{1. 서 론}

현대 사회는 핑크칼라의 시대라 불릴 만큼 여성들의 사회 진 출이 활발하게 늘어나서 생활양식의 변화와 더불어 의복의 형 태도 예술과 문화를 반영하면서 많은 변화를 가져왔으며 그에 따라 의복 패턴 제작법 역시 다양한 형태로 발전되어 왔다. 패 션 주기가 빠르게 변하면서 보다 더 체계적이고 전문화된 패턴 을 필요로 하게 되었으며, 재킷 디자인에 있어서도 폭넓은 다 양성을 추구하고 있다.

또한 여성의 사회 진출이 보편화 되면서 재킷은 현대 여성 들에게 필수적인 아이템이며 출근복으로 가장 많이 착용 되어 지는 의복 중의 하나로 착용하는 사람의 라이프스타일이나 이 미지, 특성, 사회적 지위 등이 그대로 나타난다고 할 수 있다. 이러한 중요한 의복인 재킷 패턴에 대한 연구가 활발하게 이루 어져 왔으며 현재까지도 여러 종류의 재킷 패턴 연구는 계속

$\dagger$ Corresponding author; Jung-A Song

Tel. +82-54-530-1314, Fax. +82-54-530-1319

E-mail: jasong@knu.ac.kr
되고 있다.

재킷의 선행연구를 살펴보면, Park and Song(2009)은 양장 기능사 실기시험에 적합한 빠른 시간 내에 패턴을 제작할 수 있는 재킷 패턴을 제시하였으며, 소재별 특성에 따른 재킷 패 턴 연구(Choi, 2008; Jang, 2006; Koo, 2009)와 체형에 관한 재킷 패턴 연구(Kang, 2008; Kim, 2009; Kim, 2004), 칼라에 관한 패턴 연구(Kim, 2007; Lee, 2011), 노년의 재킷 패턴 연 구(Bae, 2006; Jung, 2007; Lee, 2006)와, 재킷에 대한 이미지 나 만족도에 관한 연구(Han, 2005; Han, 1996; Park, 2003) 등이 있다.

하지만 대부분의 재킷 연구들은 현대 여성들이 선호하는 한 개 단추 여밈 재킷에 대한 연구(Han, 2005; Kang, 2008; $\mathrm{Kim}, 2004)$ 들은 많으나 재킷의 꺽임선과 여밈 단추 수에 따른 다양한 패턴의 변화와 패턴 설계 방법에 대한 연구는 미비한 실정이다.

따라서 본 연구는 한 가지 스타일의 테일러드 재킷 패턴을 이용해서 재킷의 라펠 꺽임선에 따라 달라지는 칼라 패턴의 변 화를 알아보고 재킷의 여밈 단추 수에 따른 전체적인 패턴 변 화를 도출하는 것이 목적이다. 


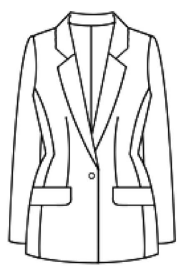

(a)

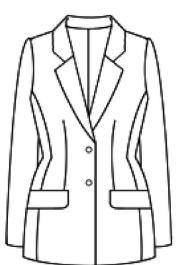

(b)

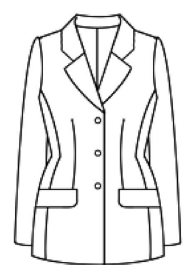

(c) (d)

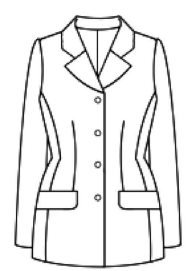

Fig. 1. Jacket styles; (a) 1-button jacket, (b) 2-button jacket, (c) 3-button jacket, (d) 4-button jacket.

\section{2. 연구방법 및 내용}

본 연구에서는 재킷의 라펠 꺽임선과 라펠 너비를 다르게 적 용하여 테일러드 재킷 실험복을 대상으로 한 개 단추, 두 개 단추, 세 개 단추, 네 개 단추 여밈 테일러드 재킷의 칼라의 너비와 길이의 변화, 라펠의 너비와 길이의 변화, 라펠 꺽임선 의 각도와 버튼 수의 상관관계, 전체적인 디자인의 조화 등 4 종류의 테일러드 재킷의 칼라 제작시에 나타나는 다양하게 변 화된 패턴 설계 방법을 제시하였다.

연구에 사용된 재킷 패턴은 Park and Song(2009)의 테일러 드 재킷 패턴 제도 방법으로 제도하였다. 간단하면서도 빠른 시 간 내에 패턴을 제작할 수 있게 간략하게 되어 있고 테일러드 재킷의 특성과 형태를 비교적 잘 표현되어 있어 실루엣이 자연 스럽게 나타나 있다.

연구 절차는 Park and Song(2009)의 논문을 통하여 조사한 세 개 단추 여밈 테일러드 재킷의 제도 방법을 분석 하였고, 꺽 임선의 각도와 위치에 따라서 4종류(한 개 단추, 두 개 단추, 세 개 단추, 네 개 단추)의 테일러드 재킷 도식화를 분석한 후 1 차 는 라펠 너비를 $7.5 \mathrm{~cm}$ 로 같은 치수를 적용하여 4종류의 재킷 을 제작하고 착의 실험을 한 후, 2 차는 라펠 너비의 치수를 다 르게 적용하여서 한 개 단추 여밈 재킷은 라펠 너비 $8.5 \mathrm{~cm}$ 를 적용하고, 두 개 단추 여밈 재킷에는 라펠 너비 $8 \mathrm{~cm}$ 를 적용, 네 개 단추 여밈 재킷에는 라펠 너비 $7.5 \mathrm{~cm}$ 를 1 차와 동일하
Table 1. Measurements for jacket pattern

\begin{tabular}{|c|c|c|c|}
\hline View & Part & Body dimension & $\operatorname{Size}(\mathrm{cm})$ \\
\hline \multirow{12}{*}{ Bodice } & \multirow{3}{*}{ Girth } & bust girth & 87 \\
\hline & & waist girth & 68 \\
\hline & & hip girth & 94 \\
\hline & \multirow{5}{*}{ Length } & jacket length & 65 \\
\hline & & neck to waist length & 38 \\
\hline & & front length & 40.5 \\
\hline & & neck to nipple length & 24 \\
\hline & & waist to hip & 18 \\
\hline & \multirow{4}{*}{ Width } & shoulder width & 39 \\
\hline & & back width & 36 \\
\hline & & chest width & 34 \\
\hline & & nipple to nipple breadth & 18 \\
\hline \multirow{2}{*}{ Sleeve } & Girth & cuff size & 25 \\
\hline & Length & sleeve length & 58 \\
\hline
\end{tabular}

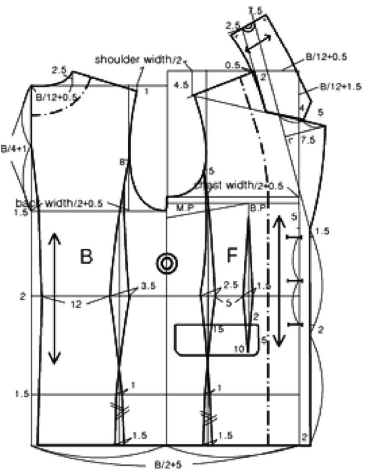

(a)

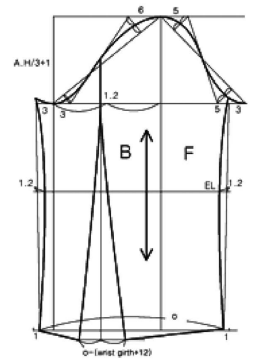

(b)
Fig. 2. Basis pattern of three-button jacket; (a) bodice, (b) Sleeve.

게 적용하였다. 세 개 단추 여밈은 Park and Song(2009)의 패 턴 그대로 $7.5 \mathrm{~cm}$ 를 적용하였다. 선행논문(Park \& Song, 2009)에서 라펠너비 $7 \mathrm{~cm}$ 를 적용했을 때 칼라의 너비가 작고

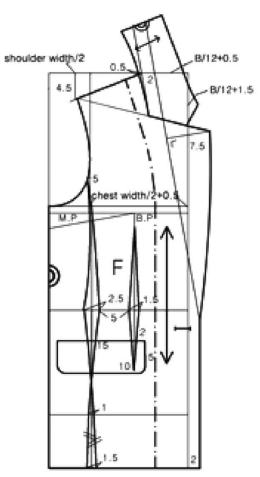

(a)

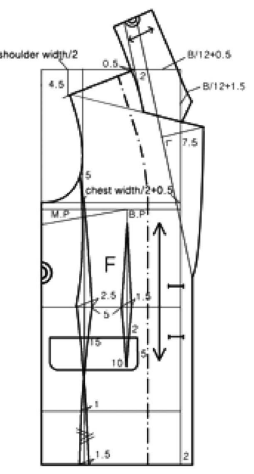

(b)

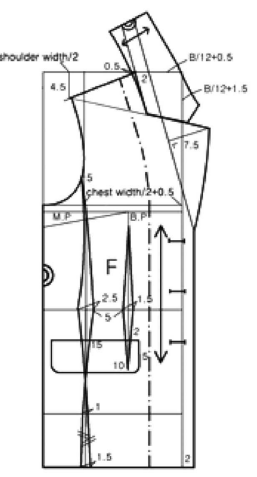

(c)

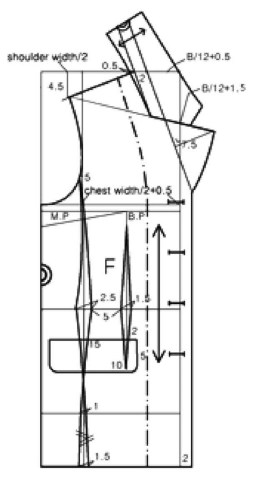

(d)

Fig. 3. Patterns for the first experimental jacket; (a) 1-button jacket pattern, (b) 2-button jacket pattern, (c) 3-button jacket pattern, (d) 4-button jacket pattern. 
지 않기로 하였다. 설정된 실험 조건에 따라 머슬린으로 실험 용 재킷을 제작하고 드레스폼에 입혀 착의실험을 하고, 라펠의 치수를 다르게 적용해서 선정된 제작방법에 따라 머슬린으로 2 차 실험 재킷을 제작하고, 이를 1 차 실험 재킷과 비교, 분석하 였다.

선행 연구 논문에서 추출한 패턴을 기본 패턴으로 4 벌의 재 킷을 제작 하였고, 착장 평가에 대한 객관적인 평가를 위해 전 문지식이 있는 석사학위과정이상의 패션학 전공자 8 명을 검사 자로 구성하였다.

평가항목은 Park and Song(2009)의 선행 연구에서 실시한 방법을 참고로 칼라에 대한 항목을 더 추가하여 길, 칼라, 소 매, 전체 실루엣 등 20 항목으로 선정하였다.

평가방법은 4 개의 실험용 재킷을 같은 크기의 드레스폼에 동 일한 조건으로 착의 후 검사자로 하여금 같은 시간에 같은 장 소에서 외관을 평가하게 하였고, 자료 분석은 SPSS 12.0 통계 프로그램을 이용하여 외관 착장 평가 결과에 대하여 4 종류의 실험용 재킷의 평균과 표준편차를 구하여 분석하였다.

1 차 실험용 재킷을 비교 분석하고 2 차로 라펠의 치수만 다 르게 적용해서 실험용 재킷 치수와 동일하게 패턴을 설계한 후 1 차 실험용 재킷 착장 평가 결과를 바탕으로 변화된 칼라와 라 펠의 디자인을 파악하여 재킷을 제작하였다.

1 차 실험용 재킷과 같은 조건으로 착장 평가를 실시하고 그 차이를 비교 분석하였다.

\section{3. 연구 결과 및 고찰}

\subsection{1차 실험용 재킷 패턴 치수 비교}

적용치수는 Park and Song(2009)의 세 개 단추 여밈 재킷 의 치수를 참고로 하여, 한 개 단추, 두 개 단추, 네 개 단추 여밈 재킷의 칼라 적용 치수는 칼라 꺽임 $2.5 \mathrm{~cm}$, 칼라 너비 $7.5 \mathrm{~cm}$, 길과 겹침 분량 $0.5 \mathrm{~cm}$, 라펠 너비 $7.5 \mathrm{~cm}$ 의 각각 동 일한 치수를 적용하고, 라펠 꺽임선 시작점의 치수는 다르게 적 용해서 한 개 단추 여밈 재킷은 라펠 꺽임선 시작점을 진동 깊이 선을 기준으로 아래로 $19 \mathrm{~cm}$ 를 적용했고, 두 개 단추 여
Table 2. Comparison of the the first experimental jacket patterns' size

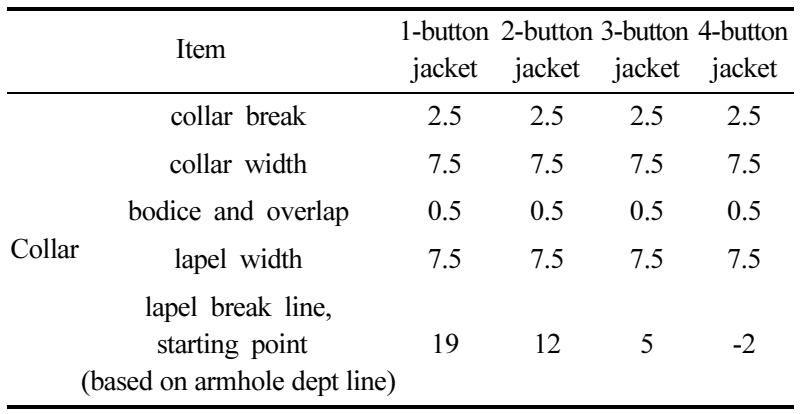

밈 재킷은 아래로 $12 \mathrm{~cm}$, 세 개 단추 여밈 재킷은 아래로 $5 \mathrm{~cm}$, 네 개 단추 여밈 재킷은 위로 $2 \mathrm{~cm}$ 올려서 적용했다.

\subsection{1 차 실험용 재킷 착장 평가}

착장 평가 결과 Table 3 과 같이 한 개 단추 여밈 재킷의 항목 중 길은 단추와 포켓 위치가 5점으로 가장 높게 나타났 고 옆 라인이 가장 낮은 점수를 보였으며 칼라는 모든 항목이 5점으로 크기와 비율이 적당하고 아름답게 나타났으며 소매와 전체 실루엣도 5점으로 높게 나타났으며 평균 4.96으로 평가 되었다.

두 개 단추 여밈 재킷은 길의 단추 위치가 가장 높은 5 점으 로 나타났지만 칼라와 소매, 전체 실루엣의 평균 점수는 4.78 로 평가 되었다.

세 개 단추 여밈 재킷은 칼라와 라펠 비율이 가장 낮은 점 수를 보였고 평균 점수가 4.73으로 평가 되었다.

네 개 단추 여밈 재킷은 길과 칼라, 소매, 전체 실루엣 중 칼라와 전체 실루엣 점수가 낮게 나타났고 라펠 길이가 1.88 로 가장 낮은 점수를 보였으며 평균 3.55로 평가 되었다. 칼라에 비해서 라펠이 밑으로 많이 쳐져서 상대적으로 칼라가 커 보여 전체적인 칼라 모양이나 실루엣이 아름답지 못하게 나타났다.

\subsection{2차 실험용 재킷 패턴 설계}

1 차 실험용 재킷의 착의평가를 분석해보면 칼라에서 낮은 점

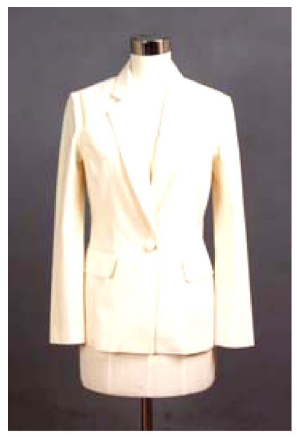

(a)

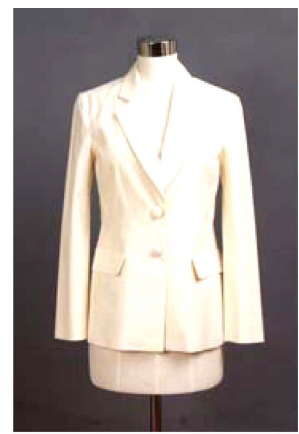

(b)

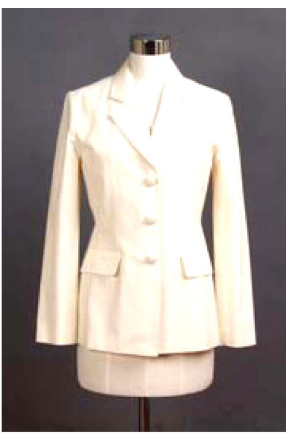

(c)

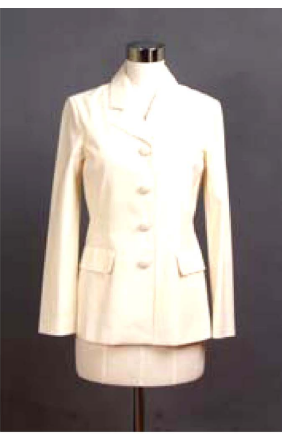

(d)

Fig. 4. The first experimental jackets; (a) 1-button jacket pattern, (b) 2-button jacket pattern, (c) 3-button jacket pattern, (d) 4-button jacket pattern. 
Table 3. Experimental external appearance test result of jacket

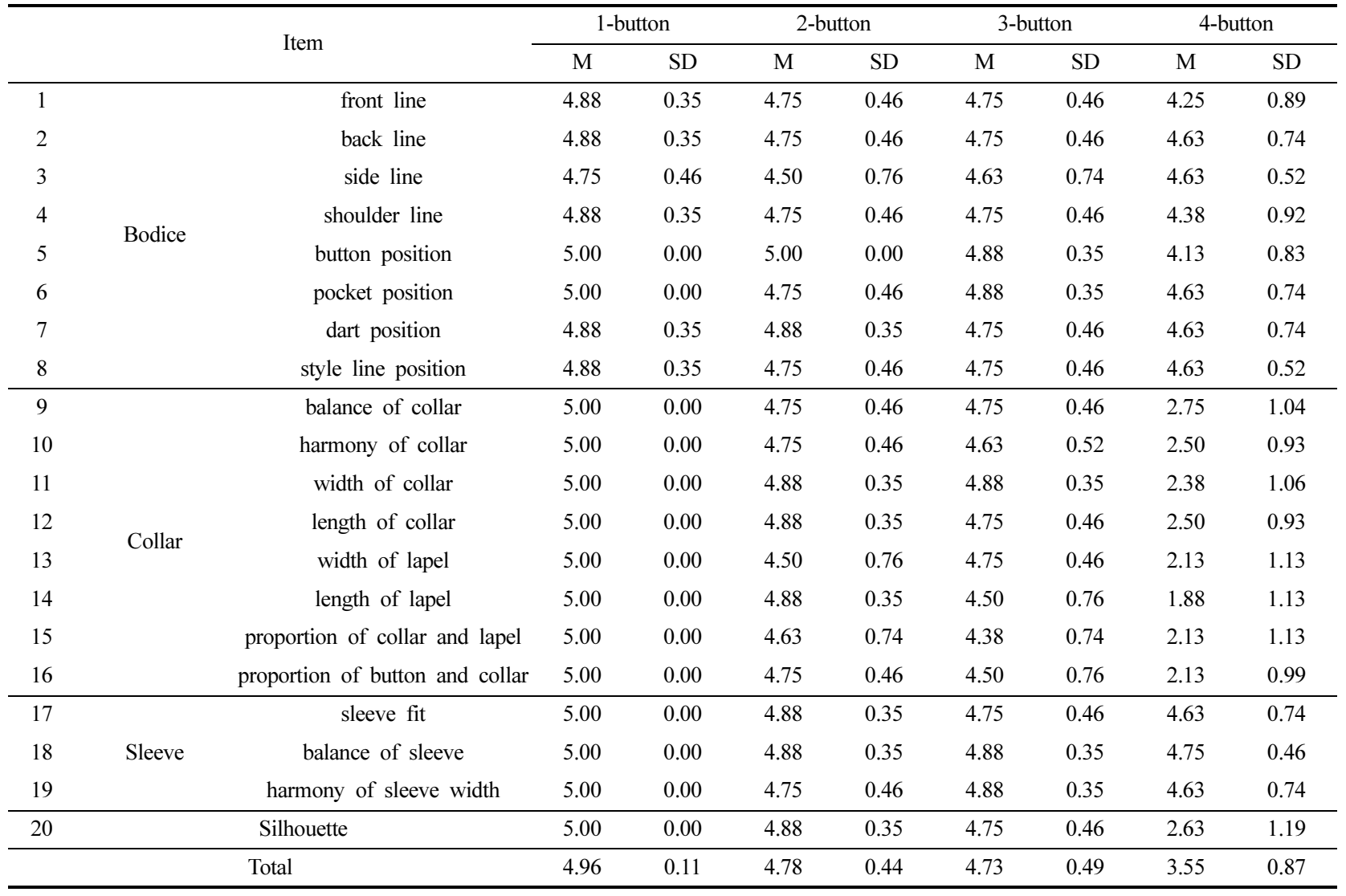

수를 보여서 각 여밈 단추별로 라펠 너비와 그에 균형을 맞추 어 윗 칼라 패턴을 수정하여 2 차 패턴을 설계하였다.

\subsection{2차 실험용 재킷 패턴 치수 비교}

선행연구의 세 개 단추 여밈 재킷은 제외하고 한 개 단추, 두 개 단추, 네 개 단추 여밈 재킷의 칼라 적용 치수는 칼라 꺽임과 칼라 너비, 길과 겹침 분량은 각각 1 차와 동일한 치수 를 적용하고, 라펠 너비는 한 개 단추 여밈 재킷은 $8.5 \mathrm{~cm}$, 두
개 단추 여밈 재킷은 $8 \mathrm{~cm}$, 네 개 단추 여밈 재킷은 $7.5 \mathrm{~cm}$ 를 적용하고, 라펠 꺽임선 시작점은 한 개 단추 여밈 재킷은 진동 깊이 선을 기준으로 아래로 $19 \mathrm{~cm}$ 를 적용했고, 두 개 단추 여 밈 재킷은 아래로 $12 \mathrm{~cm}$, 네 개 단추 여밈 재킷은 위로 $2 \mathrm{~cm}$ 올려서 각각 $7 \mathrm{~cm}$ 의 간격을 두었다.

1 차 실험용 재킷 패턴 칼라를 분리해서 겹쳐 놓고 패턴을 비 교, 분석한 결과 라펠 너비를 같은 치수를 적용했을 때 한 개 단추, 두 개 단추, 세 개 단추 여밈 재킷 칼라의 크기는 거의

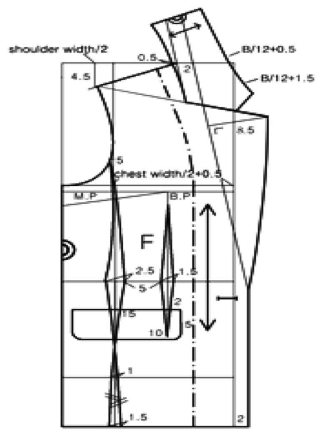

(a)

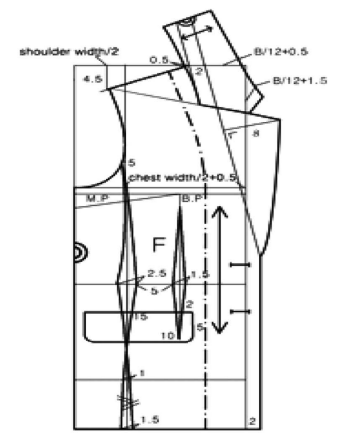

(b)

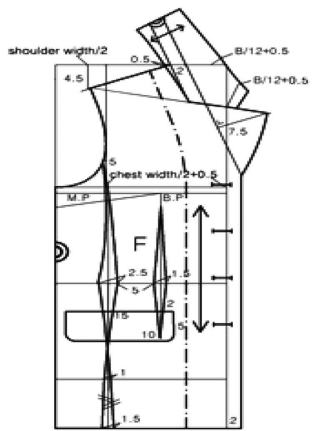

(c)

Fig. 5. Patterns for the second experimental jackets; (a) modified 1-button jacket pattern, (b) modified 2-button jacket, (c) modified 4-button jacket pattern. 
Table 4. Comparison of the second experimental jacket patterns' size

\begin{tabular}{|c|c|c|c|c|c|}
\hline & Item & Modified 1-button & Modified 2-button & Modified 3-button & Modified 4-button \\
\hline \multirow{5}{*}{ Collar } & collar break & 2.5 & 2.5 & 2.5 & 2.5 \\
\hline & collar width & 7.5 & 7.5 & 7.5 & 7.5 \\
\hline & bodice and overlap & 0.5 & 0.5 & 0.5 & 0.5 \\
\hline & lapel width & 8.5 & 8 & 7.5 & 7.5 \\
\hline & $\begin{array}{l}\text { lapel break line, starting point } \\
\text { (based on armhole dept line) }\end{array}$ & 19 & 12 & 5 & -2 \\
\hline
\end{tabular}

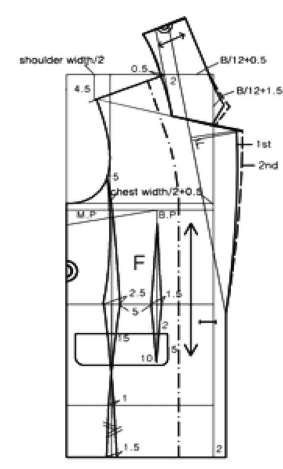

(a)

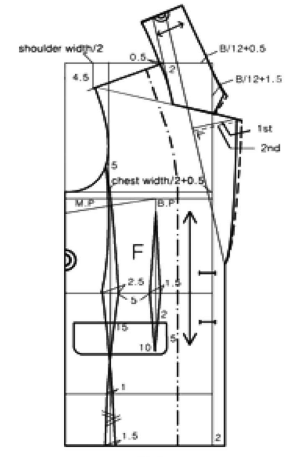

(b)

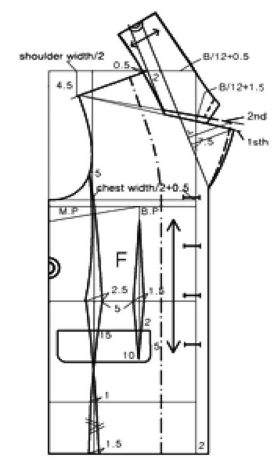

(c)

Fig. 6. Comparison of the first and the second experimental jacket pattern; (a) 1-button jacket pattern, (b) 2-button jacket pattern, (c) 4-button jacket pattern.

일정한 비율로 커지지만 네 개 단추 여밈 재킷 칼라의 경우 뒷 목둘레 부분이 약 $1 \mathrm{~cm}$ 정도 더 크게 나와서 칼라 길이도 같이 길어져 균형이 맞지 않는 다는 것을 알 수 있다.

2차 실험용 재킷 패턴의 칼라를 겹쳐 놓고 칼라의 패턴 변 화를 비교, 분석한 결과 라펠 너비가 달라져도 한 개 단추, 두 개 단추 여밈 재킷일 경우 칼라의 변화는 크게 달라지지 않았 다. 하지만 네 개 단추 여밈 재킷은 수정한 치수를 적용한 결 과 칼라의 크기가 비슷하게 나타났다. 네 개 단추 여밈 재킷의 칼라를 수정할 때 라펠 기울기가 밑으로 처진 것을 위로 $1 \mathrm{~cm}$ 올려 주면서 칼라가 작아지고 라펠 끝점도 같이 위로 올라가는 것을 알 수 있듯이 칼라와 만나는 라펠 기울기에 따라서 칼라 의 크기도 달라진다는 것을 알 수 있다.

앞 중심선을 기준으로 라펠 꺽임선의 각도를 측정한 결과 한 개 단추 여밈 재킷은 $80^{\circ}$ 로 4종류의 재킷 중 가장 높게 나타 났고 라펠 꺽임선 길이는 뒷 목점까지 $52 \mathrm{~cm}$ 이며 앞판 전체의

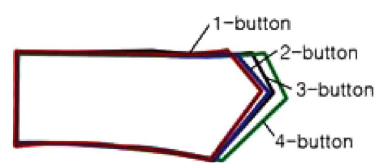

(a)

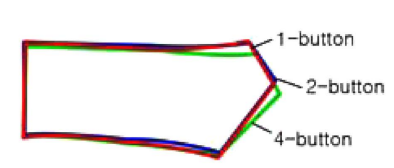

(b)
Fig. 7. Comparison of the first and the second collar patterns of experimental jackets; (a) the first experimental collar patterns, (b) the second experimental collar patterns.
길이가 $67.5 \mathrm{~cm}$ 이고 옆 목점에서 라펠 꺽임선 시작점까지의 길 이가 $41.75 \mathrm{~cm}$ 이므로 앞몸판길이와 칼라깊이의 비는 약 $1.6: 1$ 의 비율을 나타내고 있으며 칼라와 만나는 라펠 기울기는 3종 류(한 개 단추, 두 개 단추, 세 개 단추)의 재킷 모두 어깨 끝 점을 기준으로 약 $12^{\circ}$ 로 나타났다.

라펠 꺽임선의 각도가 $78^{\circ}$ 로 측정 결과가 나온 두 개 단추 여밈 재킷은 라펠 꺽임선 길이가 뒷 목점까지 $45.3 \mathrm{~cm}$ 이고 앞 몸판 길이 $67.5 \mathrm{~cm}$, 옆 목점에서 라펠 꺽임선 시작점까지의 길 이가 $34.75 \mathrm{~cm}$ 이므로 앞몸판길이와 칼라깊이의 비는 약 1.9:1 의 비율을 나타내고 있으며, 세 개 단추 여밈 재킷 라펠 꺽임 선의 각도는 $75^{\circ}$ 로 옆 목점에서 라펠 꺽임선 시작점까지의 길 이가 $27.75 \mathrm{~cm}$ 이므로 앞몸판길이와 칼라깊이의 비는 약 2.4:1 의 비율을 나타내고 있으며 라펠 꺽임선 길이는 $38.6 \mathrm{~cm}$ 로 나 왔다. 네 개 단추 여밈 재킷 라펠 꺽임선의 각도는 $70^{\circ}$ 로 4 종 류의 재킷 중 가장 낮게 나타났고 라펠 꺽임선 길이는 $32 \mathrm{~cm}$ 이며 앞 몸판 길이 $67.5 \mathrm{~cm}$, 옆 목점에서 라펠 꺽임선 시작점 까지의 길이가 $20.75 \mathrm{~cm}$ 이므로 앞몸판길이와 칼라깊이의 비는 약 3.2:1의 비율을 나타내고 있다. 칼라와 만나는 라펠 기울기 는 어깨 끝점을 기준으로 약 $10^{\circ}$ 로 나타났다. 라펠 기울기를 약 $12^{\circ}$ 로 3 종류(한 개 단추, 두 개 단추, 세 개 단추)의 재킷 과 같이 적용했을 때 라펠 기울기가 밑으로 많이 쳐지고 칼라 가 길어져 라펠 보다 칼라가 커 보여서 칼라와 라펠의 비율이 좋지 않게 나타났기 때문에 라펠 기울기의 각도를 $2^{0}$ 정도 줄여 줌으로써 칼라 길이는 작아지고 라펠 끝점도 위로 약 $1 \mathrm{~cm}$ 올 


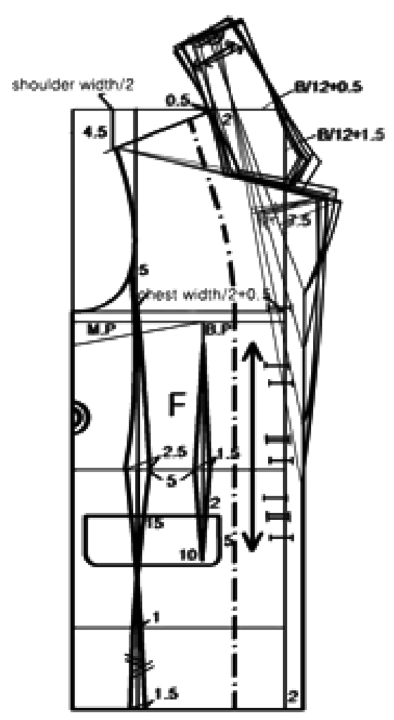

Fig. 8. Comparison of collars for the second experimental jackets.

라가서 라펠이 길어져 칼라와 라펠의 교차점이 위로 올라갔다.

라펠 꺽임선 각도는 한 개 단추 여밈 재킷과 두 개 단추 여 밈 재킷은 $2^{\circ}$ 의 차이가 났지만 세 개 단추 여밈 재킷과 네 개 단추 여밈 재킷은 $5^{\circ}$ 의 차이가 났다. 단추 수가 많아질수록 라 펠 꺽임선 각도의 차가 늘어나는 반면 라펠 꺽임선 길이는 거 의 차이가 없이 일정한 간격을 나타내고 있다.

\subsection{2차 실험용 재킷 제작 및 착장 평가}

2 차 착장 평가 결과 한 개 단추 여밈 재킷의 항목 중 길은 단추 위치가 5점으로 가장 높게 나타났고 1 차에서 높게 나타 난 포켓 위치는 4.88로 점수가 낮아졌다. 옆 라인은 1차와 같 이 가장 낮은 점수를 보였으며 칼라는 라펠 길이가 5점으로 높 은 점수를 보였고 칼라와 라펠의 비율이 4.63으로 나타났으며 소매는 소매 달린 위치가 4.75로 나왔고 소매 안정감, 소매통 아름다움, 전체 실루엣은 4.88로 동일하게 나타났고 평균 점수 가 4.84 로 평가 되었다.

두 개 단추 여밈 재킷은 길의 단추 위치, 포켓 위치, 절개선 위치가 5점으로 높게 나타났고 뒤 라인이 4.75로 낮게 나타났 다. 칼라는 칼라의 안정감, 아름다움, 칼라 길이와 너비, 라펠 너비가 5점으로 높게 나타났고 소매 안정감과 전체 실루엣이 5점으로 높게 평가 되었고 평균 점수가 4.93으로 평가 되었다.

네 개 단추 여밈 재킷은 길과 칼라, 소매, 전체 실루엣 중 칼라와 전체 실루엣 점수가 낮게 나타났지만 1차 보다는 높은 3.90 으로 평가 되었다.

착장 평가 결과 한 개 단추 여밈 재킷의 라펠 너비 $7.5 \mathrm{~cm}$ 의 테일러드 칼라가 안정적이고 칼라와 라펠의 크기와 비율이 적당하고 실루엣도 세련되고 날씬하게 나타났으며, 세 개 단추 여밈 재킷을 한 개 단추, 두 개 단추 여밈 재킷으로 칼라를 변형해도 패턴에서 큰 차이는 없는 것으로 나타났다. 세 개 단

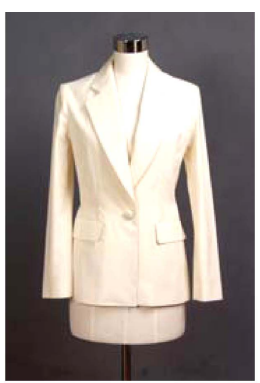

(a)

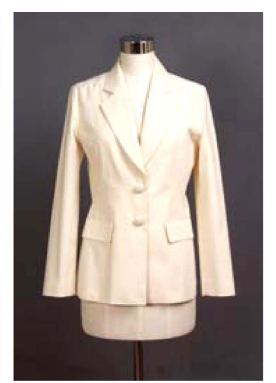

(b)

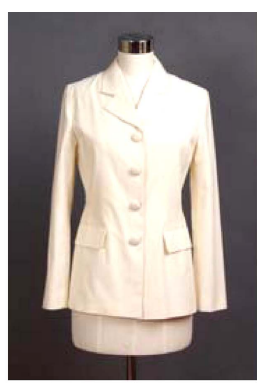

(c)
Fig. 9. The Second experimental jackets; (a) 1-button jacket, (b) 2-button jacket, (c) 4-button jacket.

추, 네 개 단추 여밈 재킷은 단추 수가 많기 때문에 한 개 단 추, 두 개 단추 여밈 재킷에 비해서 둔하고 뚱뚱해 보이는 것 으로 평가되었다.

\section{4. 결론 및 제언}

시대가 변하고 사회가 다양화 되면서 소비자의 요구 또한 더 욱 개성화되고 차별화가 됨에 따라 창의적이고 개인의 감성을 자극할 수 있는 세련된 디자인 표현력과 기술이 더 많이 요구 되고 있다. 패션의 흐름 또한 빠르게 변하면서 보다 더 세분화 된 체계적인 패턴을 필요로 하게 되었다.

본 연구는 테일러드 재킷 꺽임선에 따라 달라지는 칼라 패 턴의 변화를 알아보기 위해 선행 논문에서 연구한 재킷 패턴에 라펠 너비와 단추 수를 다르게 적용하여서 칼라 꺽임선에 변화 를 주어 한 개 단추, 두 개 단추, 세 개 단추, 네 개 단추 여 밈 재킷 패턴을 설계한 후 머슬린으로 재킷을 제작하였다. 1차 착의 실험을 통해 패턴을 수정, 보완하였고 수정, 보완된 패턴 으로 실험 재킷을 제작하고 2 차 착의 실험을 통해 패턴상의 차 이를 비교, 분석한 결과는 다음과 같다.

실험복 재킷 라펠 너비 $7.5 \mathrm{~cm}$ 의 한 개 단추 여밈 테일러드 재킷은 라펠 꺽임선의 각도가 $80^{\circ}$ 로 앞 몸판과 칼라의 비율이 약 1.6:1로 조화롭고 아름답게 표현되어 선호도가 가장 높게 나 타났다. 라펠 너비 $8.5 \mathrm{~cm}$ 는 칼라에 비해서 라펠 너비가 크고 길이가 짧아 보여 균형이 맞지 않게 나타났다. 라펠 꺽임선 각 도가 $78^{\circ}$ 인 두 개 단추 여밈 테일러드 재킷은 라펠 너비 $7.5 \mathrm{~cm}$ 보다 $8 \mathrm{~cm}$ 일 때가 더 좋게 나타났지만 그 차이는 미미 한 수준이었고 앞 몸판과 칼라의 비율은 약 1.9:1로 나타났다. 세 개 단추 여밈 테일러드 재킷 라펠 꺽임선 각도는 $75^{\circ}$ 로 나 왔고 앞 몸판과 칼라의 비율은 약 2.4:1로 나타났다. 네 개 단 추 여밈 테일러드 재킷은 라펠 꺽임선의 각도가 $70^{\circ}$ 이고 앞 몸 판과 칼라의 비율이 약 $3.2: 1$ 로 나타났다. 라펠 너비 $7.5 \mathrm{~cm}$ 를 적용했을 때 칼라와 만나는 라펠의 경사가 밑으로 많이 쳐져서 칼라는 크고 라펠의 길이는 짧아져서 균형도 맞지 않고 선호도 도 가장 낮게 나타났다.

또한 한 개 단추, 두 개 단추, 세 개 단추 여밈 재킷은 라 
Table 6. Experimental external appearance test result of jacket

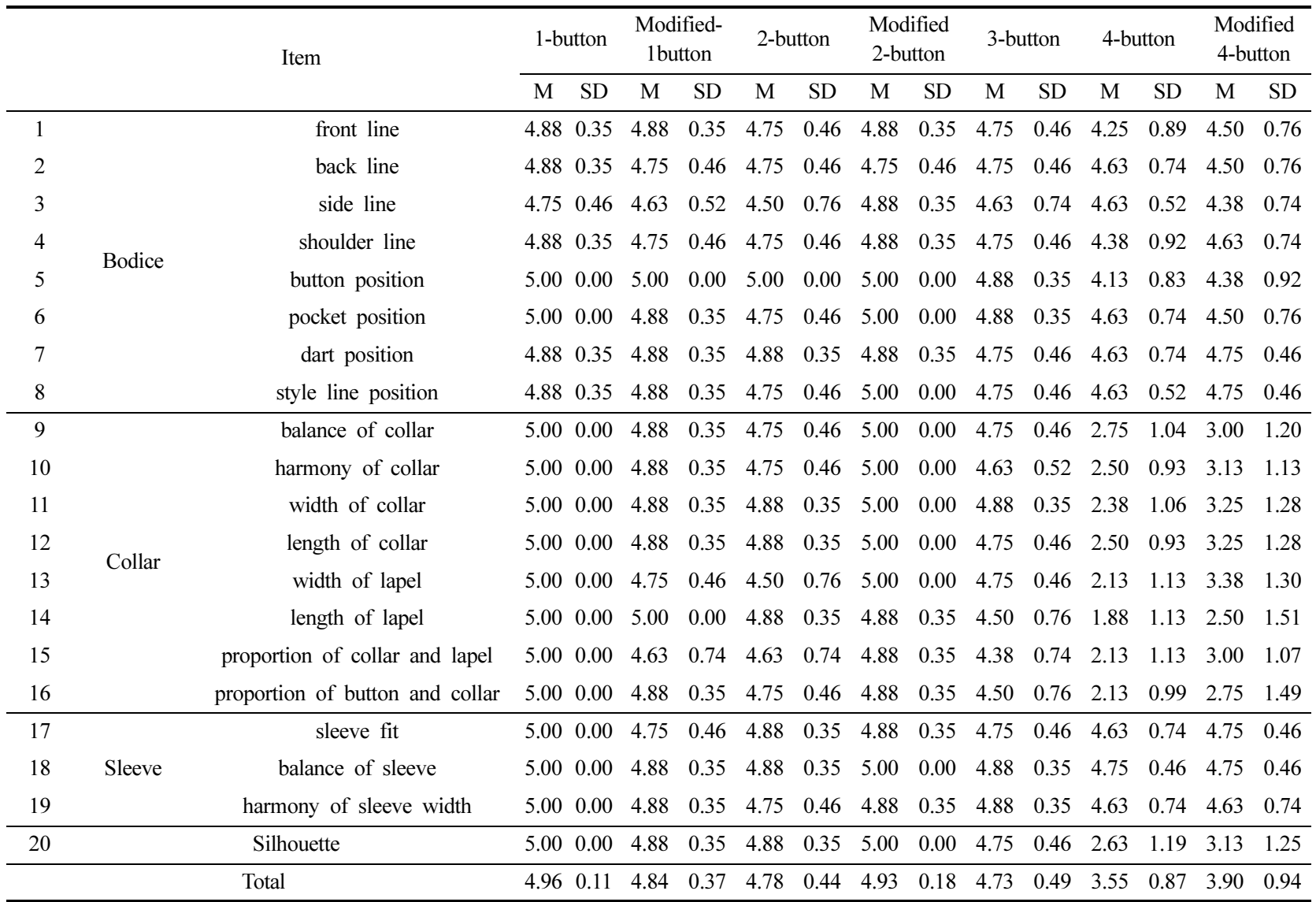

5-very good, 4-good, 3-neutral, 2-bad, 1-very bad

펠 꺽임선의 각도와 라펠 너비를 다르게 적용해도 칼라 패턴에 는 거의 변화가 없었지만, 네 개 단추 여밈 재킷은 칼라와 만 나는 라펠 기울기가 맞지 않아서 칼라와 라펠의 수정과 보완이 같이 이루어져야 했고, 라펠 기울기도 약 $2^{0}$ 정도 줄여 주었다. 기본 세 개 단추 여밈 재킷 패턴을 이용해서 네 개 단추 여밈 재킷으로 변형할 경우 적당하지 않은 것으로 나타났다.

라펠 꺽임선의 각도가 높을 수록 여밈 단추 수는 적어지고 라펠의 길이가 길고, 세련되고, 우아하고, 날씬해 보이는 것으 로 평가되었고, 라펠 꺽임선의 각도가 낮을 수록 여밈 단추 수 도 많아지고 길이가 짧고, 둔하고, 뚱뚱해 보이는 것으로 평가 되었고 재킷의 선호도도 낮아지는 것으로 나타났다.

테일러드 재킷 제작시 원단의 부피나 재질, 색상, 디자인 뿐 만 아니라 라펠 꺽임선의 위치, 라펠 너비와 길이, 단추 수에 따라서 전체적인 재킷의 이미지와 실루엣에 아주 많은 영향을 미친다는 것을 알 수 있다.

본 연구는 재킷 꺽임선에 따른 칼라의 차이를 연구하여 재 킷의 전체적인 패턴 변화를 알아내어 패턴을 공부하는 이들에 게 도움을 주고자 하였다. 하지만 실험 소재와 디자인, 색상, 실험자의 연령과 성별이 다양하지 않고 패턴 제도법 또한 광범 위하게 다루지 못했기 때문에 연구의 한계점이 있다.
후속연구에서는 라펠의 소재와 색상, 디테일을 다양하게 이 용해서 여러 가지 패턴 제도법을 적용하여 재킷의 패턴 변화와 시각적인 변화 등 다양한 패턴 연구가 이루어져야 할 것이다.

\section{감사의 글}

이 논문은 2012학년도 경북대학교 학술연구비에 의하여 연구 되었음(This research was supported by Kyungpook National University Research Fund, 2012).

\section{References}

Bae, J. H. (2006). A Study on the jacket pattern for elderly women. Unpublished doctoral dissertation, Kyung-Hee University, Seoul. Choi, C. S. (2008). A study on the development of jacket pattern in proportion to stretch fabric -Based on the middle-aged women-. Unpublished master's thesis, Konkuk University, Seoul.

Han, K. S. (2005). A study on consumer satisfaction depending on the pattern of jackets's original patterns -with a focus on local female bBrands-. Unpublished master's thesis Kookmin University, Seoul. 
Han, J. S. (1996). Visual effects of design variations in tailored jackets -Length of collar, number of buttons, and single/double variation. Unpublished master's thesis, Keimyung University, Seoul.

Jang, S. E. (2006). A study on the pattern by the traits of fabrics of women's tailored jackets. Unpublished master's thesis, Graduate School of Sookmyung Women's University, Seoul.

Jung, E. O. (2007). A study on the development of jacket pattern for the elderly men. Unpublished master's thesis, Dongduk Women's University, Seoul.

Kang, Y. K. (2008). A study for the development of a tailored suit pattern for the Chinese adult women-focused on the women in their early 20s in Shanghai-. Unpublished doctoral dissertation, Sookmyung Women's University, Seoul.

Kim, H. S. (2004). Jacket patterns planning of woman in twenties. Unpublished master's thesis, Konkuk University, Seoul.

Kim, G. Y. (2007). A study on the collar construction factors of the women's tailored jacket. Unpublished master's thesis, Changwon University, Changwon.

Kim, M. O. (2009). The patternmaking of men's sSlim-fit jacket focusing on men in the 30's-. Unpublished doctoral dissertation, Hanyang University, Seoul.
Koo, M. R. (2009). A study on formal knit jacket patterns based on types of jacquard -Focused on the Hound's Tooth PatternUnpublished doctoral dissertation, Hanyang University, Seoul.

Lee, S. Y. (2011). A study on the character of collar andlapels according to collar laying amount -focused on tailored jacket-. Journal of the Korean Society of Clothing and Textiles, 35(4), 421430.

Lee, M. S. (2006). A study on the development of jacket pattern for the elderly women. Unpublished master's thesis, Dongduk Women's University, Seoul.

Park, M. K. \& Song, J. A. (2009). The study on jacket pattern in craftsman women's wear pattern examination. Journal of the Korean Society for Clothing Industry, 12(6), 781-788.

Park, J. H. (2003). The image evaluation and the preference of tailored jacket according to the body tybe and the degree of satisfaction with their body-Focused on women in middle age-. Unpublished doctoral dissertation, Keimyung University, Daegu.

(Received 5 February 2012; 1st Revised 18 April 2012; 2nd Revised 3 September 2012; Accepted 10 October 2012)

Copyright (C) The Korean Society for Clothing Industry. 2012. This is an open access article distributed under the terms and conditions of the Creative Commons Attribution Non-Commercial license (http://creativecommons.org/licenses/by-nc/3.0/), which permits unrestricted non-commercial use, distribution, and reproduction in any medium, provided the original work is properly cited. 